\title{
Front Matter: Volume 11651
}

, "Front Matter: Volume 11651," Proc. SPIE 11651, Optical Diagnostics and Sensing XXI: Toward Point-of-Care Diagnostics, 1165101 (9 April 2021); doi: $10.1117 / 12.2596617$

SPIE. Event: SPIE BiOS, 2021, Online Only 


\section{PROGRESS IN BIOMEDICAL OPTICS AND IMAGING}

\section{Optical Diagnostics and Sensing XXI: Toward Point-of-Care Diagnostics}

Gerard L. Coté

Editor

6-11 March 2021

Online Only, United States

Sponsored and Published by

SPIE

Volume 11651 
The papers in this volume were part of the technical conference cited on the cover and title page. Papers were selected and subject to review by the editors and conference program committee. Some conference presentations may not be available for publication. Additional papers and presentation recordings may be available online in the SPIE Digital Library at SPIEDigitalLibrary.org.

The papers reflect the work and thoughts of the authors and are published herein as submitted. The publisher is not responsible for the validity of the information or for any outcomes resulting from reliance thereon.

Please use the following format to cite material from these proceedings:

Author(s), "Title of Paper," in Optical Diagnostics and Sensing XXI: Toward Point-of-Care Diagnostics, edited by Gerard L. Coté, Proceedings of SPIE Vol. 11651 (SPIE, Bellingham, WA, 2021) Seven-digit Article CID Number.

ISSN: 1605-7422

ISSN: 2410-9045 (electronic)

ISBN: 9781510641372

ISBN: 9781510641389 (electronic)

Published by

SPIE

P.O. Box 10, Bellingham, Washington 98227-0010 USA

Telephone +1 3606763290 (Pacific Time) · Fax +1 3606471445

SPIE.org

Copyright (c) 2021, Society of Photo-Optical Instrumentation Engineers.

Copying of material in this book for internal or personal use, or for the internal or personal use of specific clients, beyond the fair use provisions granted by the U.S. Copyright Law is authorized by SPIE subject to payment of copying fees. The Transactional Reporting Service base fee for this volume is $\$ 21.00$ per article (or portion thereof), which should be paid directly to the Copyright Clearance Center (CCC), 222 Rosewood Drive, Danvers, MA 01923. Payment may also be made electronically through CCC Online at copyright.com. Other copying for republication, resale, advertising or promotion, or any form of systematic or multiple reproduction of any material in this book is prohibited except with permission in writing from the publisher. The CCC fee code is $1605-$ $7422 / 21 / \$ 21.00$.

Printed in the United States of America by Curran Associates, Inc., under license from SPIE.

Publication of record for individual papers is online in the SPIE Digital Library.

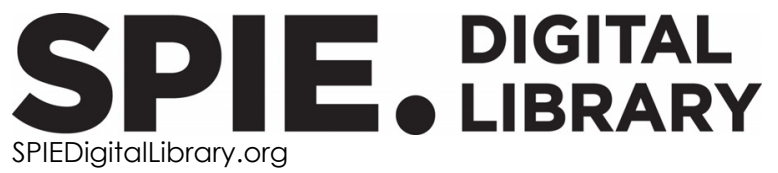

Paper Numbering: Proceedings of SPIE follow an e-First publication model. A unique citation identifier (CID) number is assigned to each article at the time of publication. Utilization of CIDs allows articles to be fully citable as soon as they are published online, and connects the same identifier to all online and print versions of the publication. SPIE uses a seven-digit CID article numbering system structured as follows:

- The first five digits correspond to the SPIE volume number.

- The last two digits indicate publication order within the volume using a Base 36 numbering system employing both numerals and letters. These two-number sets start with $00,01,02,03,04$, 05, 06, 07, 08, 09, 0A, OB ... 0Z, followed by 10-1Z, 20-2Z, etc. The CID Number appears on each page of the manuscript. 


\section{Contents}

OPICALMONITORING OF BODY RUIDS I: FOC US ON WNG DISEASE AND COVID-19

1165103 Surface plasmon resonance (SPR) based biosensor for myc obacterium tuberc ulosis diagnosis [11651-15]

1165104 ATR based infrared spectroscopy for the diagnosis of neonatal respiratory distress syndrome [11651-16]

OPIICAL MONITORING OF BODY RUIDS II: TOWARD POINT-OF-CARE SYSIEMS

1165108 Illumination compensation algonithm forcolonimetric detection of mic rofluidic paper-based devices with a smartphone [11651-20]

1165109 Development of paper-based colorimetric assays for monitoring gestational diabetes at the point-of-care [11651-21]

11651 OC Towards point-of-care detection of mic roRNAs using paper-based mic rofluidics [11651-24]

IMAGING AND MONITORING BLOOD HEMODYNAMICS

11651 OD Blood pressure estimation using sech functions pulse decomposition [11651-1]

11651 OE Non-contact measurement of pulse wave in rats using an RGB camera [11651-2]

NEAR INRARED SENSING AND IMAGING OF TISSUE

11651 OL Testing the safety of a c ustom NIRS sensor designed to monitor spinal cord hemodynamics [11651-12]

11651 ON A portable polyanatomic optico-impedance system for early waming of systemic disease: evaluation in occult hemonhage [11651-14]

MICROSCOPY TOWARD POINT-OF-CARE IMAGING SYSTEMS

1165100 Application of deep-ultraviolet mic roscopy in hematological assessment of neutropenia [11651-6] 
11651 OP A nano-illumination microscope with $7 \mathbf{~ m m}^{2}$ extended field-of-view and resolution below $1 \mu \mathrm{m}$ [11651-7]

OPTICALMONITORING OF TISSUE AND TISSUE IMPLANIS

11651 0T Diffuse reflectance spectroscopy based blood oxygenation monitoring: a prospective study for early diagnosis of diabetic foot [11651-27]

11651 oU Design selection of a fully-implantable and optically-transduced glucose biosensorvia Monte Carlo modeling [11651-28]

\section{POSTER SESSION}

11651 oW Preliminary investigation of the robustness of a fluorescent measuring system for in-line and real-time monitoring of blood-pH in extracomoreal circulation [11651-30]

11651 0X Detection of mycobacterium tuberc ulosis using gold nanopartic les conjugated to TB antibodies [11651-31]

11651 oY Agreement between body surface and rectal temperature in cats [11651-32] 